\title{
Herbage Yields and Water-use Efficiency on a Loamy Site as Affected by Tillage, Mulch, and Seeding Treatments
}

\author{
WILLIAM A. BERG AND PHILLIP L. SIMS
}

\section{Abstract}

The effects of surface treatments alone and with seeding of an introduced bluestem (Bothriochloa ischaemum) on herbage yields and water-use efficiency on a loamy range site in poor condition were studied. The study was in a 560-mm average annual precipitation area in the Southern Great Plains. Prior to treatment, buffalograss (Buchloe dactyloides) and silver bluestem (Bothriochloa saccharoides) produced the bulk of the herbage on the site. Disking or furrowing the native range produced no measureable change in herbage yields or in water-use efficiency as compared to no treatment (control) over the 5-year study period. Furrowing plus sand fill in the furrows or a rock mulch resulted in greater $(P<.05)$ herbage yields than from the control. However, most of the increased yield was by silver bluestem, a species that is ranked low in palatability. Establishment of the introduced bluestem 'Plains' increased herbage yield 2- to 4-fold and significantly increased water-use efficiency.

Sandy soils of the Great Plains have the potential to produce more aboveground phytomass than finer-textured soils (Heerwagen 1958, Harlan 1958, Tomanek 1964). This is apparently because

Authors are soil scientist and research range scientist, U.S. Department of Agriculture, Agricultural Research Service, Southern Plains Range Research Station, 200018 th Street, Woodward, Okla. 73801. This study was initiated by P.T. Koshi and E.H. McIlvain, both now retired. Their work in planning and setting up the study is gratefully acknowledged by the authors.

Manuscript received August 2, 1982. on sandy soils the infiltration rate is greater, evaporation is less, and little water is lost to percolation because much of the precipitation is received during the growing season.

If herbage production on loamy soils in poor range condition is to be increased, an approach would be to emulate the morefavorable soil-moisture conditions of sandy soils. Thus, treatments or management to increase infiltration, decrease water loss by evaporation, and favor taller-growing grass species over the short grasses might be considered.

Soil surface manipulation, such as contour furrowing, to detain and infiltrate water has been successful in increasing forage production on some soils. The greatest plant growth responses have been reported on medium to fine-textured soils (Langley and Fisher 1939, Branson et al. 1966) and in areas where snow is a substantial part of the effective precipitation (Neff and Wight 1977). Rauzi (1975) hypothesized that more intensive treatments than pitting or furrowing were needed to improve some range sites. He found that moldboard plowing or rotovating increased herbage yields over a 5-year period on clay loam and fine sandy loam soils dominated by blue grama (Bouteloua gracilis) in northeastern Wyoming.

Mulches can enhance infiltration and reduce evaporation rates. Sand and gravel 2- to 5-cm thick over unvegetated clay loam soils conserved about $70 \%$ of the $58 \mathrm{~cm}$ of precipitation falling in a 
1-year period as compared to $18 \%$ on bare fallow (Corey and Kemper 1968). Similar results were shown by Linden (1970), who found that $2.5 \mathrm{~cm}$ of gravel over a nonvegetated sandy loam soil in eastern Colorado resulted in soil retention of $50 \%$ of the precipitation over a 2-year period while retention in fallow was $13 \%$.

Interseeding sideoats grama (Bouteloua curtipendula) into a mixture of grasses which had invaded abandoned cropland increased herbage yield by $60 \%$ on a clay loam soil on the Texas High Plains (Willard and Schuster 1971). Seeding and management of weeping lovegrass (Eragrostis curvula) or the Old World bluestems (Bothriochloa spp.) in monocultures have greatly increased forage and beef production on sandy soils in northwestern Oklahoma (Shoop et al. 1976, Sims and Dewald 1982).

In our study, tillage, sand and rock mulch treatments, and combinations of these treatments plus interseeding of an introduced bluestem were applied to a loamy range site which was in poor range condition. The objective was to measure herbage yields by major species as a function of the treatments which were applied to increase water-use efficiency.

\section{Study Area and Design}

The study site was on an upland with a $7 \%$ north-facing slope in Harper County, northwestern Oklahoma. The plots were on the middle third of a smooth, $160 \mathrm{~m}$ long slope. Moderate to heavy grazing and major drouths in the 1930's and 1950's probably influenced the species composition, which was dominated by buffalograss (Buchloe dactyloides). Other perennial species present in decreasing order of aboveground phytomass production were silver bluestem (Bothriochloa saccharoides), blue grama, purple threeawn (Aristida purpurea), sand dropseed (Sporobolus cryptandrus) and sideoats grama. The annual, Japanese brome (Bromus japonicus), was common in years with greater fall and winter precipitation. Although Japanese brome is naturalized, its yield is included as part of the native vegetation in this discussion. Western

Table 1. Herbage yields on native range as affected by surface treatments.

\begin{tabular}{|c|c|c|c|c|c|c|c|c|}
\hline \multirow[b]{2}{*}{ Treatment } & \multirow[b]{2}{*}{ Year } & \multicolumn{7}{|c|}{ Species } \\
\hline & & Buda \& Bogr $\dagger$ & Bosa & Spcr & Arpu & Other grasses & Forbs & Total \\
\hline Control & $\begin{array}{c}1976 \\
1977 \\
1978 \\
1979 \\
1980 \\
5 \text { Year Mean }\end{array}$ & $\begin{array}{r}495 \\
1120 \\
690 \\
750 \\
720\end{array}$ & $\begin{array}{l}330 \\
300 \\
245 \\
540 \\
510\end{array}$ & $\begin{array}{r}60 \\
185 \\
60 \\
40 \\
20\end{array}$ & $\begin{array}{r}\mathrm{cg} / \mathrm{ha}- \\
150 \\
165 \\
135 \\
50 \\
35\end{array}$ & $\begin{array}{r}20 \\
40 \\
45 \\
100 \\
55\end{array}$ & $\begin{array}{r}105 \\
75 \\
135 \\
300 \\
170\end{array}$ & $\begin{array}{l}1160 \\
1885 \\
1310 \\
1780 \\
1510 \\
1530 \mathrm{ct}\end{array}$ \\
\hline Disking & $\begin{array}{c}1976 \\
1977 \\
1978 \\
1979 \\
1980 \\
\text { 5 Year Mean }\end{array}$ & $\begin{array}{l}430 \\
985 \\
755 \\
670 \\
630\end{array}$ & $\begin{array}{l}300 \\
250 \\
310 \\
420 \\
580\end{array}$ & $\begin{array}{r}135 \\
340 \\
250 \\
145 \\
70\end{array}$ & $\begin{array}{r}100 \\
120 \\
90 \\
50 \\
50\end{array}$ & $\begin{array}{r}40 \\
110 \\
75 \\
85 \\
115\end{array}$ & $\begin{array}{l}175 \\
100 \\
110 \\
295 \\
195\end{array}$ & $\begin{array}{l}1180 \\
1905 \\
1590 \\
1665 \\
1640 \\
1595 \mathrm{bc}\end{array}$ \\
\hline Furrowing & $\begin{array}{c}1976 \\
1977 \\
1978 \\
1979 \\
1980 \\
\text { 5 Year Mean }\end{array}$ & $\begin{array}{l}345 \\
910 \\
690 \\
600 \\
560\end{array}$ & $\begin{array}{l}365 \\
600 \\
390 \\
745 \\
650\end{array}$ & $\begin{array}{r}70 \\
230 \\
160 \\
65 \\
45\end{array}$ & $\begin{array}{r}110 \\
115 \\
65 \\
40 \\
20\end{array}$ & $\begin{array}{r}90 \\
235 \\
80 \\
265 \\
145\end{array}$ & $\begin{array}{l}130 \\
140 \\
105 \\
325 \\
175\end{array}$ & $\begin{array}{l}1110 \\
2230 \\
1490 \\
2040 \\
1595 \\
1695 \text { abc }\end{array}$ \\
\hline Sand Mulch & $\begin{array}{c}1976 \\
1977 \\
1978 \\
1979 \\
1980 \\
\text { 5 Year Mean }\end{array}$ & $\begin{array}{r}405 \\
! 2 ! 0 \\
845 \\
845 \\
790\end{array}$ & $\begin{array}{l}305 \\
410 \\
235 \\
410 \\
405\end{array}$ & $\begin{array}{r}120 \\
335 \\
100 \\
75 \\
50\end{array}$ & $\begin{array}{r}85 \\
110 \\
100 \\
85 \\
95\end{array}$ & $\begin{array}{r}50 \\
105 \\
20 \\
75 \\
65\end{array}$ & $\begin{array}{r}200 \\
45 \\
70 \\
200 \\
155\end{array}$ & $\begin{array}{c}1165 \\
2215 \\
1370 \\
1690 \\
1560 \\
1600 \mathrm{bc}\end{array}$ \\
\hline Disking + Sand & $\begin{array}{c}1976 \\
1977 \\
1978 \\
1979 \\
1980 \\
5 \text { Year Mean }\end{array}$ & $\begin{array}{l}250 \\
775 \\
520 \\
750 \\
505\end{array}$ & $\begin{array}{l}330 \\
435 \\
410 \\
320 \\
755\end{array}$ & $\begin{array}{r}165 \\
410 \\
195 \\
85 \\
30\end{array}$ & $\begin{array}{r}75 \\
145 \\
110 \\
55 \\
75\end{array}$ & $\begin{array}{r}75 \\
100 \\
95 \\
380 \\
90\end{array}$ & $\begin{array}{l}210 \\
415 \\
245 \\
365 \\
135\end{array}$ & $\begin{array}{l}1105 \\
2280 \\
1575 \\
1955 \\
1590 \\
1700 \mathrm{abc}\end{array}$ \\
\hline $\begin{array}{l}\text { Furrowing + Sand in } \\
\text { Furrow }\end{array}$ & $\begin{array}{c}1976 \\
1977 \\
1978 \\
1979 \\
1980 \\
\text { 5 Year Mean }\end{array}$ & $\begin{array}{l}170 \\
630 \\
410 \\
445 \\
390\end{array}$ & $\begin{array}{r}495 \\
430 \\
450 \\
1320 \\
1160\end{array}$ & $\begin{array}{r}110 \\
465 \\
210 \\
110 \\
20\end{array}$ & $\begin{array}{r}100 \\
130 \\
85 \\
65 \\
35\end{array}$ & $\begin{array}{r}70 \\
425 \\
125 \\
415 \\
460\end{array}$ & $\begin{array}{l}200 \\
355 \\
150 \\
335 \\
210\end{array}$ & $\begin{array}{l}1145 \\
2435 \\
1430 \\
2690 \\
2275 \\
1995 \mathrm{a}\end{array}$ \\
\hline Rock Mulch & $\begin{array}{c}1976 \\
1977 \\
1978 \\
1979 \\
1980 \\
\text { 5 Year Mean }\end{array}$ & $\begin{array}{l}355 \\
645 \\
480 \\
400 \\
270\end{array}$ & $\begin{array}{r}74 \\
530 \\
430 \\
1710 \\
1230\end{array}$ & $\begin{array}{l}110 \\
380 \\
150 \\
100 \\
145\end{array}$ & $\begin{array}{r}110 \\
150 \\
75 \\
10 \\
10\end{array}$ & $\begin{array}{r}75 \\
145 \\
85 \\
240 \\
325\end{array}$ & $\begin{array}{l}250 \\
115 \\
225 \\
245 \\
150\end{array}$ & $\begin{array}{l}974 \\
1965 \\
1445 \\
2705 \\
2130 \\
1845 \mathrm{ab}\end{array}$ \\
\hline
\end{tabular}

+Buda = Buchloe dacyloides, Bogr $=$ Bouteloua gracilis, Bosa $=$ Bothriochloa saccharoides, Sper $=$ Sporobolus cryptandrus, Arpu $=$ Aristida purpurea .

$\ddagger 5$ year means followed by the same letter are not significantly different $(P<0.05)$. 
ragweed (Ambrosia psilostachya) was the most abundant forb on the site.

The soil, which developed from calcareous, fine-grained, soft sandstone, is representative of extensive areas of weakly developed, moderately deep soils on Permian redbeds in the Southern Plains. The soil is classified as a coarse-silty, mixed, thermic Typic Ustochrept of the Woodward series. The texture to a depth of 0.5 to $1 \mathrm{~m}$ was a loam. Organic matter in the top $15 \mathrm{~cm}$ was $2.4 \%$. Depth to $\mathrm{CaCO}_{3}$ ranged from 10 to $29 \mathrm{~cm}$, and depth to redbed ranged from 0.5 to $1 \mathrm{~m}$. The redbeds are very weakly consolidated; strata may range from a few centimeters to a meter or more in thickness, and from sandy loam to clay loam in texture.

The range condition of this loamy range site (Soil Conservation Service 1960) is poor as most of the herbage production is by buffalograss (herbage production up to $5 \%$ allowed as an increaser) and silver bluestem (an invader). Tomanek and Albertson (1957) described an ungrazed mixed prairie on soils derived from Permian redbeds near Ashland, Kans., (60 km north of our study site) as being dominated by sideoats grama and little bluestem (Schizachyrium scoparium). They also reported that the basal area of buffalograss increased from less than $5 \%$ of all vegetation to $90 \%$ under heavy grazing.

Precipitation measured at the study site was $560 \mathrm{~mm}$ in 1976,490 $\mathrm{mm}$ in 1977 , and $360 \mathrm{~mm}$ in 1978. Precipitation was not measured at the study site in 1979 and 1980 . For these years, precipitation measured at the USDA Southern Plains Experimental Range $4 \mathrm{~km}$ to the south was 670 and $430 \mathrm{~mm}$, respectively. The long-term average annual precinitation at the Experimental Range is $560 \mathrm{~mm}$ with $70 \%$ received from April through September. Pan evaporation from April through September averages 1,320 mm per year.

Precipitation received during the growing season was 392,325 , 487 , and $196 \mathrm{~mm}$ for the periods $25 \mathrm{Apr}$. to $10 \mathrm{Oct}$. $1977,30 \mathrm{Mar}$. to 5 Oct. 1978, 20 Apr. to 9 Sept. 1979, and 29 Apr. to 6 Sept. 1980, respectively. Soil water depletion over these same periods was estimated by using the neutron scattering technique to determine water present to a depth of $1.8 \mathrm{~m}$ by 20 -cm increments on the given spring date minus water present on the fall date for each plot. Water-use efficiency was calculated by dividing herbage production by the sum of growing season precipitation and soil water depletion. Installation of the neutron probe access tubes was not completed until the fall of 1976; thus water-use efficiencies were not calculated for that year.

The treatments applied to the native vegetation in April 1976 were:

1. Control. No treatment.

2. Disking. Use of a heavy-duty double disk which severed an estimated $50 \%$ of the crown cover of existing vegetation.

3. Furrowing. Small furrows $5 \mathrm{~cm}$ deep and $10 \mathrm{~cm}$ wide on 27 $\mathrm{cm}$ spacing made on the contour.

4. Sand mulch. Two $\mathrm{cm}$ of medium and fine sand $(99 \%$ passed a $5 \mathrm{~mm}$ sieve) was placed directly on the vegetation.

5. Disking + sand mulch. The treatment was disked as in treatment 2 and then $2 \mathrm{~cm}$ of sand was applied to the surface.

6. Furrowing + sand in furrows. The treatment was furrowed as in treatment 3 and then the furrows were filled with sand.

7. Rock mulch. Flat, fine-textured sandstones 15 to $30 \mathrm{~cm}$ in diameter and 4 to $8 \mathrm{~cm}$ thick were placed on the vegetation to give about about $70 \%$ ground cover.

8. Introduced bluestem + sand mulch. An Old World bluestem (Bothriochloa ischaemum var. 'Plains') (Taliaferro et al. 1972) was broadcast at a rate of $2 \mathrm{~kg} /$ ha pure live seed and then $2 \mathrm{~cm}$ of sand was placed over the seed.

9. Disking, introduced bluestem + sand mulch. Disked as in treatment 2 then broadcast seeded with 'Plains' bluestem and the seed covered with $2 \mathrm{~cm}$ of sand.

10. Furrowing, introduced bluestem + sand in furrow. Furrowed as in treatment 3 , broadcast seeded with 'Plains' bluestem and then the furrows were filled with sand.
Each treatment plot was $4 \times 4 \mathrm{~m}$ assigned randomly within replication with the limitation that disking treatments or furrowing treatments were adjacent to each other to facilitate use of the equipment. Five replications were used. Each replication was on the contour separated by a 9-m buffer of native vegetation from the adjacent replication. The plots were fenced to exclude livestock. In the early spring of each year the standing vegetation was mowed to a height of 3 to $5 \mathrm{~cm}$, with the exception of the rock mulch plots which were not mowed.

Yields were estimated by micro-unit forage inventory (Shoop and Mcllvain 1963), which is a weight-estimate method using a $29.2 \times 66.0-\mathrm{cm}$ quadrat. Twenty-four quadrats were read on each plot in October, 1976 through 1980.

Analyses of variance on herbage yields and on water-use efficiency were made using data from all 10 treatments and again using only the data from the 7 surface treatments on the native species. This was done because yields on the 3 introduced bluestem treatments were 2 - to 4 -fold greater than yields of the native species. The greater yields on the introduced bluestem treatments were accompanied by greater absolute variability which gave an unrealistically large error term for testing the lower-yielding native range treatments. Means for significant $(P<.05)$ main effects in the analysis of variance on herbage yields were separated using Duncan's multiple range test.

\section{Results and Discussion}

\section{Native Vegetation}

Disking or furrowing of native range, the 2 surface treatments which could be applied over extensive areas, resulted in no significant differences in herbage yields as compared to the control within any 1 year or over the 5 -year period (Table 1). After 5 years, the disked plots were not discernable and the furrows were faint. Thus, although the disking and furrowing treatments appeared drastic when applied, they had little impact on total herbage yield or the proportion of herbage produced by the major individual species. The sand mulch or disking plus sand mulch treatments also resulted in herbage yields similar to those on the control.

Furrowing plus sand-fill in the furrows or the rock mulch treatments resulted in greater $(P<.05)$ herbage yields than from the control over the 5-year period but not within any 1 year (Table 1 ). The greater herbage yields on the rock mulch and sand-filled furrow treatments was largely due to an increase in production of silver bluestem. This mid grass is regarded as an invader on this site (Soil Conservation Service, 1960) and is rated low in palatability (U.S. Department Ágriculturê, 1948). These data (Tabie i) indicate that a change in species composition to midgrasses should result in greater herbage yields. However, there was no indication of invasion or increased forage yields by more-desirable midgrasses such as sideoats grama or little bluestem. Sideoats grama was present in minor amounts on many of the plots but showed no measurable change in forage yields with the surface treatments. Little bluestem was abundant on shallower soils within $100 \mathrm{~m}$ of the treatments. Thus, it appears that any relatively short-term attempt to increase forage production by the more-desirable native midgrasses will need to include seeding them as well as intensive treatment to reduce competition from buffalograss and silver bluestem.

\section{Introduced Bluestem Seeding}

Herbage yields during the 1977 through 1980 growing seasons were 2- to 4-fold greater on treatments interseeded to the introduced bluestem than on the native range treatments (Table 2). In 1976, the year that the bluestem was interseeded, the introduced bluestem produced $29 \%$ of the herbage on the bluestem seeding treatments; native species produced the remainder. In 1977, 1978, 1979 , and 1980 the introduced bluestem produced $72,79,84$, and 92\% of the herbage on the interseeded bluestem treatments, respectively. 
Table 2. Mean herbage yields on all surface treatments on native range as compared to mean yields on treatments interseeded to an introduced bluestem.

\begin{tabular}{lccccc}
\hline \hline & \multicolumn{5}{c}{ Year } \\
\cline { 2 - 5 } Treatment & 1976 & 1977 & 1978 & 1979 & 1980 \\
\hline & & & $-k g / h a$ & - & \\
Native range & $1130 \mathrm{a}$ & $2130 \mathrm{~b}$ & $1460 \mathrm{~b}$ & $2075 \mathrm{~b}$ & $1750 \mathrm{~b}$ \\
Introd. bluestem & $1255 \mathrm{a}$ & $3705 \mathrm{a}$ & $3425 \mathrm{a}$ & $5465 \mathrm{a}$ & $6545 \mathrm{a}$ \\
\hline
\end{tabular}

Treatment means within years followed by the same letter are not significantly different $(P<.05)$.

There were no significant $(P<.05)$ differences among the herbage yields produced on the 3 surface treatments combined with broadcast seeding of the introduced bluestem. In retrospect, a treatment of seeding the introduced bluestem into disked or furrowed native range without a sand mulch should have been included in this study for comparison purposes.

The much greater herbage yields on the introduced bluestem treatments as compared to native range treatments were not unexpected as they are similar to yields of Old World bluestems grown on sandy soils on the Southern Plains Experimental Range $4 \mathrm{~km}$ to the south. (Sims and Dewald 1982). The introduced bluestems are more readily established by seeding than are the native grass species. However, mixed stands of Old World bluestems and native grasses could pose grazing management problems in that cattle may selectively graze many of the native species. The principal use of the Old World bluestems now appears to be in reestablishment of grasslands on marginal farmlands.

\section{Soil Water}

Soil water recharge from 8 December 1976 to 8 June 1977 averaged $5.3 \mathrm{~cm}$ of water among all treatments as measured by the difference in volumetric soil water between these 2 dates (Table 3 ).

Table 3. Winter and spring recharge of soil water over the periods 8 December 1976 to 8 June 1977, and 22 December 1977 to 7 June 1978 as affected by surface and seeding treatments on native range.

\begin{tabular}{lcc}
\hline & \multicolumn{2}{c}{ Recharge period } \\
\cline { 2 - 3 } & $12 / 8 / 76$ to & $12 / 22 / 77$ to \\
Treatment & $6 / 8 / 77$ & $6 / 7 / 78$ \\
\hline & $-c m$ of water \pm 1 std. crror-- \\
Control & $6.0 \pm 0.4$ & $10.9 \pm 0.4$ \\
Disking & $4.2 \pm 0.6$ & $10.9 \pm 0.6$ \\
Furrowing & $4.4 \pm 0.7$ & $11.5 \pm 0.5$ \\
Sand mulch & $6.5 \pm 0.5$ & $11.8 \pm 0.9$ \\
Disking + sand mulch & $5.1 \pm 0.6$ & $11.6 \pm 0.4$ \\
Furrowing + sand in furrows & $2.6 \pm 0.7$ & $12.0 \pm 0.3$ \\
Rock mulch & $6.7 \pm 0.4$ & $12.2 \pm 1.0$ \\
Introduced bluestem + sand mulch & $6.9 \pm 0.2$ & $12.6 \pm 0.6$ \\
Disking, introduced bluestem + sand & $7.2 \pm 0.6$ & $12.1 \pm 0.7$ \\
mulch & & \\
Furrowing, introduced bluestem + & & $13.7 \pm 0.5$ \\
$\quad$ sand in Furrows $\quad$ Trt. (ANOVA) & $4.0 \pm 0.8$ & $\mathrm{NS}$ \\
\hline
\end{tabular}

* indicates 0.01 level of significance

The recharge from 22 December 1977 to 7 June 1978 averaged 11.9 $\mathrm{cm}$. Although there were differences $(P<.01)$ in recharge among treatments in June 1977, there appear to be no consistent differences in recharge among treatments over the years. In this study there was usually a good cover of vegetation over the soil as the plots were mowed only once a year and then late in the dormant season. Under these conditions the effect of a rock or sand mulch in limiting evaporation would be minimized. The recharge data are subject to the limitation that transpiration in April, May, and early June reduced recharge, and that water lost by transpiration may not have been the same for all treatments. In 1979 and 1980 , years with above-average spring rain, nearly all plots recharged to $1.8 \mathrm{~m}$, the depth to which neutron probe access tubing was installed. Runoff was not measured on this study, but averaged $3 \mathrm{~cm} / \mathrm{yr}$ over the 1977-1980 period from areas with similar soils, vegetation, and topography at Woodward, Okla., $25 \mathrm{~km}$ south of the study site (unpublished data, S.J. Smith, USDA-ARS, Durant, Okla).

Water-use efficiencies calculated for the 6 different surface treatments on the native range were not different $(P<.05)$ from the control (Table 4). Establishing the introduced bluestem significantly $(P<.01)$ increased water-use efficiency as compared to the

Table 4. Water-use efficiency in herbage production during four growing seasons as affected by surface treatments or seeding an introduced bluestem plus surface treatments on native range. Expressed as $\mathrm{kg}$ herbage per hectare per $\mathrm{cm}$ water depleted \pm one standard error of the mean.

\begin{tabular}{lcccc}
\hline \hline & \multicolumn{4}{c}{ Year } \\
\cline { 2 - 5 } Treatment & 1977 & 1978 & 1979 & 1980 \\
\hline Control & $45 \pm 3$ & $38 \pm 4$ & $32 \pm 4$ & $39 \pm 3$ \\
Disking & $43 \pm 2$ & $46 \pm 16$ & $30 \pm 3$ & $40 \pm 4$ \\
Furrowing & $51 \pm 4$ & $43 \pm 2$ & $37 \pm 4$ & $37 \pm 16$ \\
Sand mulch & $54 \pm 14$ & $36 \pm 2$ & $31 \pm 4$ & $36 \pm 4$ \\
Disking + sand mulch & $52 \pm 1$ & $43 \pm 5$ & $34 \pm 2$ & $39 \pm 6$ \\
Furrowing + sand in furrows & $55 \pm 5$ & $42 \pm 4$ & $51 \pm 11$ & $49 \pm 13$ \\
Rock mulch & $49 \pm 4$ & $37 \pm 4$ & $49 \pm 13$ & $49 \pm 8$ \\
$\quad$ Surface treatments on native & & & & \\
$\quad$ species (ANOVA) & $\mathrm{NS}$ & $\mathrm{NS}$ & $\mathrm{NS}$ & $\mathrm{NS}$ \\
$\begin{array}{l}\text { Introd. bluestem + Sand } \\
\quad \text { Mulch }\end{array}$ & $78 \pm 17$ & $96 \pm 20$ & $77 \pm 9$ & $142 \pm 37$ \\
$\begin{array}{l}\text { Disking, introd. bluestem + } \\
\quad \text { sand mulch }\end{array}$ & $86 \pm 10$ & $117 \pm 16$ & $106 \pm 12$ & $169 \pm 15$ \\
$\begin{array}{l}\text { Furrowing, introd. bluestem + } \\
\quad \text { Sand in furrow }\end{array}$ & $82 \pm 15$ & $93 \pm 16$ & $105 \pm 20$ & $156 \pm 10$ \\
$\quad$ All treatments (ANOVA) & $* *$ & $* *$ & $* *$ & $* *$ \\
\hline
\end{tabular}

**Indicates 0.01 level of significance

efficiency of water used in producing herbage from the native stands (Table 4). In general, water-use efficiency paralleled herbage yields (Table 1 and 2). This was because differences in soil water depletion among the 10 treatments within a growing season tended to be small in relation to growing season precipitation.

Depletion of soil water was most-readily measured in 1980 when above-average spring precipitation resulted in recharge of the soil to a depth of $1.8 \mathrm{~m}$, this was followed by an exceptionally dry summer. Over the period 22 May to 6 September 1980 an average of $25.5 \mathrm{~cm}( \pm 1.0 \mathrm{~cm}$ std. error) of water was depleted to a depth of $1.8 \mathrm{~m}$ from the treatments, with no differences $(P<.05)$ among the treatments. The pattern of soil water depletion with depth appeared similar for all treatments with most of the water depletion occurring above $160 \mathrm{~cm}$ (Data from two treatments are shown in Table 5). Considerable variability in water depletion was found

Table 5. Soll water depletion with depth over the period 22 May to 6 September 1980 on the control and the introduced bluestem + and mulch treatments.

\begin{tabular}{lcc}
\hline \hline $\begin{array}{l}\text { Depth of } \\
\text { Measurement } \\
- \text { cm- }\end{array}$ & \multicolumn{2}{c}{ Treatment } \\
\cline { 2 - 3 } & Coptrol & $\begin{array}{c}\text { Introduced bluestem } \\
\text { + Sand Mulch }\end{array}$ \\
\hline 20 & $20 \pm 1$ & $21 \pm 1$ \\
40 & $21 \pm 1$ & $21 \pm 1$ \\
60 & $19 \pm 2$ & $19 \pm 1$ \\
80 & $14 \pm 4$ & $17 \pm 2$ \\
100 & $15 \pm 1$ & $14 \pm 4$ \\
120 & $11 \pm 3$ & $11 \pm 3$ \\
140 & $7 \pm 3$ & $10 \pm 2$ \\
160 & $5 \pm 4$ & $4 \pm 1$ \\
180 & $3 \pm 3$ & $2 \pm 1$ \\
\hline
\end{tabular}


within treatments at depths of 80 to $180 \mathrm{~cm}$ (Table 5), this probably is a reflection of varying permeability of the substratum (Permian redbed) to roots.

\section{Conclusion}

Disking or furrowing of native range dominated by buffalograss (an increaser) and silver bluestem (an invader) had no measureable effect on herbage yields or water-use efficiency. More intensive surface treatments increased the yield of silver bluestem but not of more-desirable midgrasses. It appears that seeding of desired midgrasses and control of competition from buffalograss and silver bluestem will be needed to increase forage production by native species on such sites.

Establishment of 'Plains' bluestem, an introduction from Asia, into native range greatly increased forage yields and water-use efficiency. However, grazing management of a mixture of native species and the introduced bluestem would be difficult as many of the natives would be preferentially grazed.

\section{Literature Cited}

Branson, F.A., R.F. Miller, and I.S. McQueen. 1966. Contour furrowing, pitting and ripping on rangelands of the western United States. J. Range Manage. 19:182-190.

Corey, A.T., and W.D. Kemper. 1968. Conservation of soil water by gravel mulchcs. Hydrology Paper 30, Colorado State Univ., Fort Collins.

Harlan, J.R. 1958. Grasslands of Oklahoma. Processed teaching manual, Agronomy Dept., Oklahoma State Univ., Stillwater, OK.

Heerwagen, A. 1958. Management as related to range site in the central plains of eastern Colorado. J. Range Manage. 11:5-9.
Langley, B.C., and C.E. Fisher. 1939. Some effects of contour listing on native grass pastures. J. Amer. Soc. Agron. 31:972-981.

Linden, D.R. 1970. Fallow and gravel mulch effects on soil water storage. M.S. Thesis, Colorado State University, Fort Collins.

Neff, E.L., and J.R. Wight. 1977. Overwinter soil water recharge and herbage production as influenced by contour furrowing on eastern Monrangelands. J. Range Manage. 30:193-195.

Rauzi, F. 1975. Severe mechanical and chemical range renovation in northeastern Wyoming. J. Range Manage. 28:319-326.

Shoop, M.C., and E.H. Mcllvain. 1963. The micro-unit forage inventory method. J. Range Manage. 16:172-179.

Shoop, M., E.H. Mcllvain, and P.W. Voigt. 1976. Morpa weeping lovegrass produces more beef. J. Range Manage. 29:101-103

Sims, P.L., and C.L. Dewald. 1982. Old World bluestems and their forage potential for the Southern Great Plains: A review of early studies. USDA Agr. Res. Service ARM-S-2B.

Soll Conservation Service, USDA. 1960. Technical Range Site descriptions: Loamy. Soil Conservation Service, USDA Building, Oklahoma State Univ., Stillwater, Okla.

Taliaferro, C.M., J.R. Harlan, and W.L. Richardson. 1972. Plains bluestem. Oklahoma State Univ. Agr. Exp. Sta. Bull. B-699.

Tomanek, G.W. 1964. Some soil-vegetation relationships in western Kansas. p. 158-164. In: Forage Plant Psychology and Soil-Range Relationships. Amer. Soc. Agron. Spec. Pub. 5. Madison, Wis.

Tomanek, G.W., and F.W. Albertson. 1957. Variations in cover, composition, production, and roots of vegetation on two prairics in western Kansas. Ecol. Monogr. 27:267-281.

U.S. Department of Agriculture. 1948. Grass. USDA Yearbook of Agriculture 1948. p. 792-793. U.S. Gov. Printing Office, Washington, D.C.

Willard, E.E. and J.L. Schuster. 1971. An evaluation of an interseeded sideoats grama stand four years after establishment. J. Range Manage. 24:223-226. 